\title{
Methane Emission and its Energy Potential from Municipal Solid Waste in North-Eastern Nigeria using the IPCC Methodology
}

Saeed Isa Ahmed $^{\# 1}$, Kabir Garba $^{\# 2}$ and Umar Salim Ibrahim
\#1 Department of Chemical Engineering, Abubakar Tafawa Balewa University Bauchi,
Nigeria, +2348131808280, alsaeedng @ yahoo.com
\#2 Department of Chemical Engineering, Abubakar Tafawa Balewa University Bauchi,
Nigeria, +2348039596023, kbgarba.1214@gmail.com
\#3 Department of Chemical Engineering, Abubakar Tafawa Balewa University Bauchi,
Nigeria, +2348035745947, sirliem74@gmail.com

\section{ABSTRACT}

Municipal Solid Waste (MSW) disposed in landfill sites decompose under anaerobic conditions and produce gases mainly carbon dioxide $\left(\mathrm{CO}_{2}\right)$ and methane $\left(\mathrm{CH}_{4}\right)$. Of these greenhouse gases $\mathrm{CH}_{4}$ is 25 times more potent in terms of contribution to global warming than $\mathrm{CO}_{2}$; however, $\mathrm{CH}_{4}$ is a promising renewable energy resource. Thus, this study estimated the $\mathrm{CH}_{4}$ gas emission from MSW generated in North-Eastern capital cities of Nigeria as well as its renewable energy potential in terms of electricity. The $\mathrm{CH}_{4}$ emission estimation was performed using the intergovernmental panel on climate change (IPCC) FOD methodology. Results showed that the total $\mathrm{CH}_{4}$ emissions for North-East capitals i.e. Bauchi, Damaturu, Gombe, Jalingo, Maiduguri and Yola are 1,435,282 kg; 101,042 kg; 378,330 kg; $173,021 \mathrm{~kg} ; 513,501 \mathrm{~kg}$ and $426,869 \mathrm{~kg}$ with their corresponding electricity generation potentials of 9,299 MWh (1.0615 MW), 654 MWh (0.0747 MW), 2,415 MWh (0.2798 MW), 1,121 MWh (0.128 MW), 3,398 MWh (0.3798 MW) and 2,766 MWh (0.3157 MW)respectively in the year 2017. This research provides data-base useful to government and international bodies for planning purposes.

Key words:Methane, Emissions, Municipal solid waste, North Eastern Nigeria, IPCC.

Corresponding Author:Saeed Isa Ahmed

\section{INTRODUCTION}

Landfills are among the nation's largest emitters of methane, a key greenhouse gas (GHG), and there is considerable interest in quantifying the methane emissions from landfills (Mackie, 2009). The greenhouse gases (GHGs) related to landfilling are mainly methane $\left(\mathrm{CH}_{4}\right)$ and carbon dioxide $\left(\mathrm{CO}_{2}\right)$ which are produced by anaerobic bacteria as a result of degradation of the carbon contained in the waste (IPCC, 2007a; Gardner et al., 1993). NMOCs (non-methane organic compounds) usually makes up less than $1 \%$ of landfill gas. Methane is regarded as one of the most important GHGs because its global warming potential has been estimated to be more than 20 times of that of carbon dioxide, in addition, atmospheric methane concentration has been increasing in the range of $1-2 \%$ per year (IPCC, 2007a).

Municipal solid waste (MSW) is a significant contributor to GHG emissions through degradation by microorganisms in the landfill or waste dump to give Landfill gas (LFG), 
which is approximately made up of $\mathrm{CH}_{4}$ and $\mathrm{CO}_{2}$ in ratio 1:1. Landfilling is the primary waste disposal strategy particularly in developing countries (Lou, 2009). When MSW is disposed in waste dumps and landfills most of the organic material will be bio-degraded, ranging in a wide span from less than one year to 100 years or more strongly depending on conditions in the site where the MSW is deposited; this biodegradation will either be aerobic or anaerobic (Parker et al., 2002). The $\mathrm{CH}_{4}$ produced is released to the atmosphere which contributes to global warming, thus the emissions need to be estimated and reported in national GHG inventories under the United Nations' Framework Convention on Climate Change (UNFCCC).

Standard software or methodologies are also available for LFG estimation and these include Intergovernmental Panel on Climatic Change (IPCC) and LandGEM model (IPCC, 2007, Johari et al., 2012). Table 1 shows summary of studies carried out on MSW and $\mathrm{CH}_{4}$ emission and its potentials.

Table 1. Summary of studies on $\mathrm{CH}_{4}$ emission and its potentials

\begin{tabular}{ll}
\hline Author & Work done \\
\hline Ahmed et al., & Economic and environmental evaluation of \\
landfill gas utilization: A multi-period \\
optimization approach for low carbon \\
regions. \\
Findings: Landfill Gas (GHG) estimation \\
was carried out and tools (models) were \\
developed for its optimal utilization based \\
on economic and environmental grounds. \\
The models indicated that LFG is best \\
utilized as a medium grade LFG for \\
combined heat and power generation in \\
Iskandar Malaysia.
\end{tabular}

Johari et al., Economic and environmental benefits of 2012 landfill gas from municipal solid waste in Malaysia.

Findings: From the study, based on 8,196,000 tonnes MSW generated in Peninsular Malaysia in 2010, anthropogenic $\mathrm{CH}_{4}$ emission of about 310,220 tonnes per year was estimated. To reduce the menace Scope/Limitation Focuses on GHG estimation and development of models for its optimal utilization in Iskandar Malaysia. of the GHG emission, it was proposed that the GHG can be utilized more prudently to generate 1.9 billion $\mathrm{kWh}$ of electricity/year worth over RM 570 million (US\$190 million).

$\begin{array}{ll}\text { Chalvatzaki\& } & \text { Estimation of GHG emissions from } \\ \text { Lazaridis, 2010 } & \text { landfills: application to the Akrotiri landfill }\end{array}$ site (Chania, Greece).

Findings: The maximum biogas production rate by the Land GEM model was calculated to be $1.64 \times 10^{3} \mathrm{MG} / \mathrm{yr}$ and was Focuses on GHG emission estimation using IPCC and the potential of the GHG in electricity generation in Malaysia. observed during the year 2008 for the A

Focused on determination of $\mathrm{GHG}$ emissions from the Akrotiri landfill site in Chania, Greece using Land GEM model. No scenario was proposed 
phase of the landfill, while for the B phase

to reduce emission.

the maximum biogas production rate was $2.70 \times 10^{3} \mathrm{MG} / \mathrm{yr}$ and was observed during 2014. Hoklis\& Sharp, GHG Emission from MSW in Phnom Penh,
Ca14

Jha et al., 2007 GHG emissions from MSW management in Indian mega-cities. Findings: In Chennai, emission flux ranged from 1.0 to $23.5 \mathrm{mg}$ $\mathrm{CH}_{4} / \mathrm{m}^{2} / \mathrm{h}, 6$ to $460 \mu \mathrm{g} \mathrm{N} \mathrm{N}_{2} \mathrm{O} / \mathrm{m}^{2} / \mathrm{h}$ and 39 to $906 \mathrm{mg} \mathrm{CO}_{2} / \mathrm{m}^{2} / \mathrm{h}$ at Kodungaiyur and 0.9 to $433 \mathrm{mg} \mathrm{CH} / \mathrm{m}^{2} / \mathrm{h}, 2.7$ to $1200 \mu \mathrm{g}$ $\mathrm{N}_{2} \mathrm{O} / \mathrm{m}^{2} / \mathrm{h}$ and 12.3 to $964.4 \mathrm{mg} \mathrm{CO}_{2} / \mathrm{m}^{2}$ $/ \mathrm{h}$ at Perungudi. Total $\mathrm{CH}_{4}$ emission estimates were found to be about $0.12 \mathrm{Gg}$.
Limited to GHG emission estimation and designing of ways of reducing emission via recycling and composting in Cambodia. No energy quantification was carried out. IPCC was not used.

Focuses only on GHG emission estimations at Chennai landfill sites, India. No energy quantification was carried out.

From literature, study on North Eastern Nigeria in terms of the application of IPCC methodology for GHG emission and hence its energy potential is scarce. Therefore, this study aimed at estimating the amount of $\mathrm{CH}_{4}$ emitted from MSW disposed in North-Eastern capital cities of Nigeria in 2017 as well as its energy potential using the IPCC methodology. This research was carried out using Tiers 2 and 3 methods which are based on a first order decay (FOD) emission calculations of the IPCC.

Many models are now available for GHG emission from MSW. The IPCC introduced three tiers (Tier 1, Tier 2 and Tier 3) for estimating $\mathrm{CH}_{4}$ emission from landfills in each country or locality based on MSW quality and quantity. The Tier employed depends on the information available. Tier 1 requires the least amount of information, while Tier 3 requires the most.

\section{Study Area - North-Eastern Capital Cities of Nigeria}

NigerianNorth-Eastern capital cities are the capital cities of the 6 states in northeast region of Nigeria (Figure 1). The northeastern states are made up of Adamawa, Bauchi, Borno, Gombe, Taraba and Yobe states. They are located on Latitude 9.082 and Longitude 8.6753 and occupies slightly less than one-third of Nigeria's total area. The northeastern states have a projected population, in 2017 , of $26,672,806$ people or $13.5 \%$ of the country's population. Several towns in northeastern region of Nigeria have been raided by Boko Haram militants, who engaged in violent clashes with the government authorities. Borno state has been the epicenter of the insurgency. To date, more than 20000 people have been killed and over 2 million people have fled their homes. There are over 7 million people in need of humanitarian assistance in Borno, Yobe and Adamawa states of which more than half are children (Obi 
\&Eboreime, 2015). As normalcy is returning to Northeast, there is need for data generation particularly in relation to MSW generation such as GHGs and its energy potential.

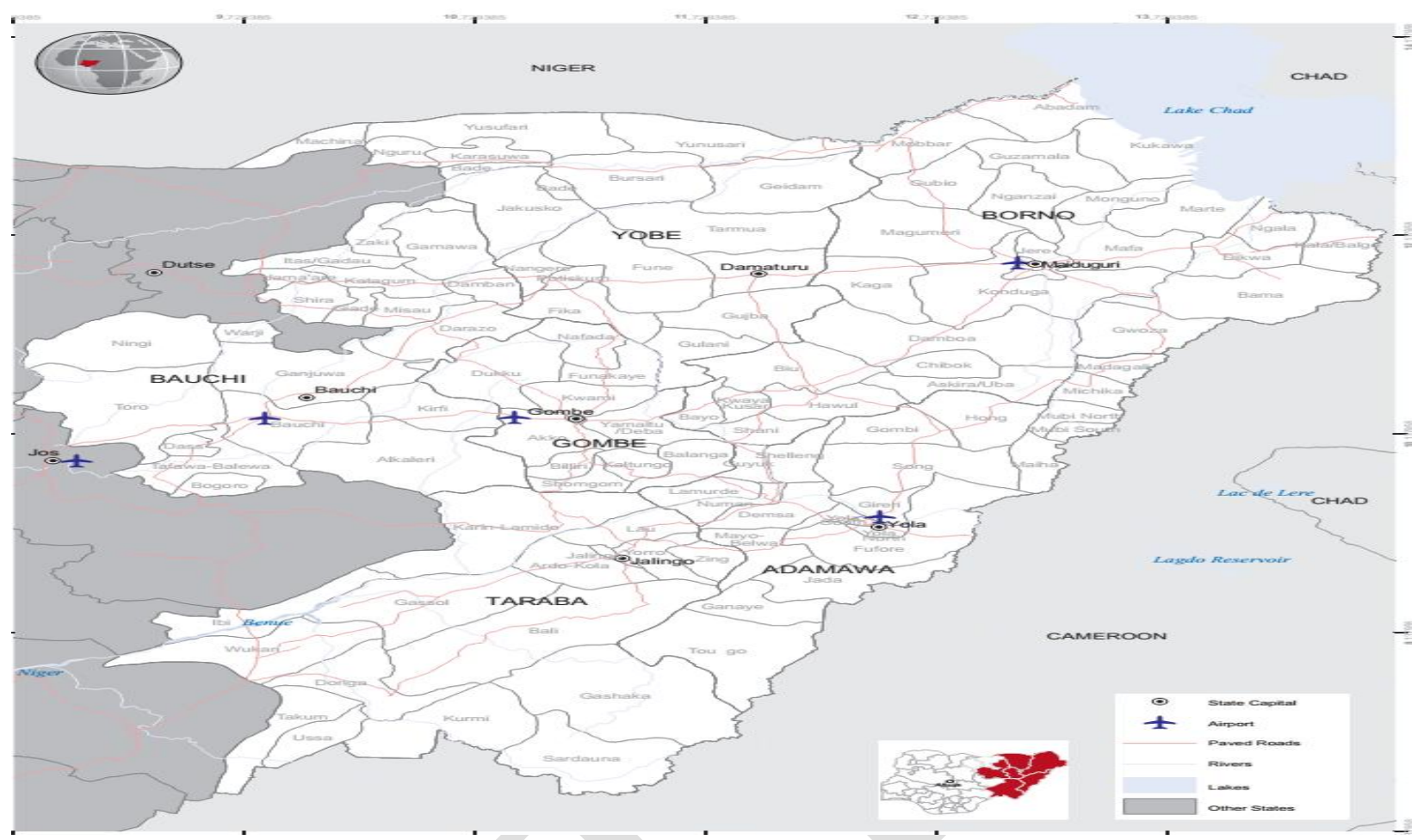

Figure 1.Geographical map showing the study area; Northeastern Capital Cities (Felix \& Yomi, 2013)

\section{MATERIALS AND METHODS Characterization of MSW}

In this work the waste characteristics of Bauchi city was taken as a typical waste characterization for the entire northeast. This is due to the similarities in terms of geographical location, economic and social status as well as cultural activities. The waste characterization was done by determination of the waste compositions in Bauchi metropolis. This involved random collection of waste samples from various dumping sites located in different areas within Bauchi metropolis. The samples were collected from six (6) different dumpsites which includes YelwanTudu, Old Airport road, Federal low-cost, Fadamanmada, Nasarawa Jahun and Sabon Kaura. The wastes with a total weight of $7.3655 \mathrm{~kg}$ were packed and stored. The collected wastes were combined and thoroughly mixed; the waste mixture was sorted manually into various components which include: food wastes, paper, plastic, textiles, rubber, ceramics, metals and glass etc. The components were dried in order to reduce their moisture content. After drying, the weight of the waste samples was determined and recorded.

\section{Municipal Solid waste Generation}

The MSW generation was determined using Eq. (1); by multiplying population, per capita waste generation and number of days in a year (Ahmed et al., 2015).

MSW= Population $\mathrm{x}$ per capita waste generated $\mathrm{x}$ number of days in a year

The MSW is the amount of MSW generated in $\mathrm{kg} / \mathrm{year}$. The per capita waste generation of $0.86 \mathrm{~kg} / \mathrm{day}$ (Bogoroet al., 2014), $0.30 \mathrm{~kg} / \mathrm{day}$ (Babalola et al., 2010), $0.38 \mathrm{~kg} / \mathrm{day}$ 
(Sulaimanet al., 2016), $0.34 \mathrm{~kg} /$ day (Tsunatuet al., 2015), $0.25 \mathrm{~kg} / \mathrm{day}$ (Dauda et al., 2003) and $0.60 \mathrm{~kg} /$ day (Liman et al., 2015) are for Bauchi, Damaturu, Gombe, Jalingo, Maiduguri and Yola respectively.

\section{Estimation of Methane}

The IPCC methodology was used to estimate amount of $\mathrm{CH}_{4}$ emitted which is based on first order decay model, meaning the degradation of the reactive component of the waste follows a first order reaction. The methane emission was estimated using Equation (2) following the procedure of Ahmed et al. (2015):

$\mathrm{CH}_{4 T}=\left[\sum_{x} \mathrm{CH}_{4}\right.$ generated $\left._{x, T}-R_{T}\right] \times\left(1-O X_{T}\right)$

where $\mathrm{CH}_{4}$ is the amount of $\mathrm{CH}_{4}$ in $\mathrm{kg}$ emitted in year $\mathrm{T}, \mathrm{T}$ is the inventory year, $\mathrm{x}$ is the waste category or type of material, $\mathrm{R}_{\mathrm{T}}$ is the recovered $\mathrm{CH}_{4}$ in year $\mathrm{T}$, and $\mathrm{OX}_{\mathrm{T}}$ is the oxidation factor in year $\mathrm{T}$, (fraction). For simplicity, $\mathrm{OX}_{\mathrm{T}}$ is taken as zero.

The amount of $\mathrm{CH}_{4}$ generated is given by Equation (3):

$$
\text { Methane } \text { generated }=D D O C_{m, \text { decomp }} * F * 16 / 12
$$

Where; $\mathrm{F}$ is the proportion of methane in LFG, and 16/12 is the ratio of molecular mass of methane to carbon.

The most important factor in the model is the amount of reactive material - decomposable degradable organic material, DDOC, remaining in the landfill at any time. The amount of this DDOC in the waste is calculated as follows IPCC, (2007a):

$D D O C_{m, T}=M S W_{m, T} * D O C * D O C_{f} * M C F$

Where, DDOC $_{\mathrm{m}, \mathrm{T}}$ is the amount of decomposable degradable organic material in year $\mathrm{T}$ in $\mathrm{kg}, \mathrm{MSW}_{\mathrm{m}, \mathrm{T}}$ is the quantity of MSW deposited in the landfill in year $\mathrm{T}$ in $\mathrm{kg}$, DOC is the amount of degradable organic carbon in the waste in $\mathrm{kg}$ carbon per $\mathrm{kg} \mathrm{MSW,} \mathrm{DOC}_{\mathrm{f}}$ is the fraction of DOC that can degrade under anaerobic condition in the landfill, MCF is the methane correction factor, i.e. the fraction of waste which is not affected by the aerobic process preceding the main anaerobic reaction. This is taken as 1 for a deep and managed landfill. The amount of $\mathrm{DDOC}_{\mathrm{m}}$ accumulates with time given as follows:

$$
D D O C_{m a, T}=D D O C_{m, T}+\left(D D O C_{m a, T-1} * e^{-k}\right)
$$

Where; $\mathrm{DDOC}_{\mathrm{ma}, \mathrm{T}}$, and $\mathrm{DDOC}_{\mathrm{ma}, \mathrm{T}-1}$ are the amounts of DDOC that have accumulated at the end of year $\mathrm{T}$ and year $\mathrm{T}-1$ respectively. $\mathrm{k}$ is the waste degradation rate constant (rate of reaction) in year ${ }^{-1}$, given by $\mathrm{k}=\ln (2) / \mathrm{T}_{1 / 2}$, and $\mathrm{T}$ is the half-life (in years). In addition, the $\mathrm{DDOC}_{\mathrm{ma}, \mathrm{T}}$ responsible for LFG generation is actually the amount that decomposed which is calculated as:

$D D O C_{m, \text { decomp }}=D D O C_{m a, T-1} *\left(1-e^{-k}\right)$

\section{Determination of energy (electricity) potential}

Electricity generations were adopted from the method of Barros et al. (2014), Amini\& Reinhart (2011) using Equation (7):

$P_{\text {electricity }}=\frac{\mathrm{CH}_{4} \text { estimated } \times \mathrm{CV}_{\mathrm{CH}}}{\mathrm{Yr}(\mathrm{sec})} \mu_{\text {equipment }}$

where $\mathrm{P}$ electricity is the electrical power in $\mathrm{MW}, \mathrm{CH}_{4 \text { estimated }}$ is amount of methane estimated from the IPCC FOD method, $\mathrm{CV}_{\mathrm{CH} 4}$ is the calorific value of methane, $\mu$ Equipment is 
the efficiency of the methane utilization equipment and Yr. $(\mathrm{sec})$ is One year converted to seconds.

\section{RESULTS AND DISCUSSION}

In this section, the municipal solid waste generation and projected population for NorthEastern capital cities of Nigeria are first presented and discussed. Then, the amount of methane emitted and the amount of electricity that can be generated in MW using the methane emission values for North-Eastern capital cities of Nigeria follows.

\section{Municipal solid waste generations and populations for North-Eastern cities of Nigeria}

Table 2 presents the projected population and MSW generation for the study areas - Bauchi, Damaturu, Gombe, Jalingo, Maiduguri and Yola metropolis for 2017. The data for the population was based on information got from National bureau for statistics, Nigeria and field work.

Table 2. Population and Municipal solid waste generation in 2017

\begin{tabular}{llll}
\hline $\mathbf{S} / \mathbf{N}$ & Cities & Population & MSW $(\mathbf{k g} / \mathbf{y r})$ \\
\hline $\mathbf{1}$ & Bauchi & 626,453 & $196,643,750$ \\
$\mathbf{2}$ & Damaturu & 128,897 & $14,114,185$ \\
$\mathbf{3}$ & Gombe & 379,351 & $52,615,845$ \\
$\mathbf{4}$ & Jalingo & 193,040 & $23,956,410$ \\
$\mathbf{5}$ & Maiduguri & $490,587.5$ & $71,625,775$ \\
$\mathbf{6}$ & Yola & 269,916 & $59,111,750$ \\
\hline
\end{tabular}

As shown in Table 2, Bauchi metropolis is the most populated city followed by Maiduguri, Gombe, Yola, Jalingo and Damaturu metropolises in that order. However, if not for the insurgence by the Boko haram in the northeast in which Borno state is the worst affected, Maiduguri should be the most populous city according to the national bureau of statistics projections.

The quantity of waste generated in these cities are due to the rapid population growth and urbanization. This requires huge financial and manpower resources for the municipalities to manage the solid wastes. With regards to the MSW generation, Bauchi metropolis has the highest amount of waste generation due to its per capital waste generation value of 0.86 $\mathrm{kg} /$ person/day as against $0.30,0.38,0.34,0.40$ and $0.60 \mathrm{~kg} / \mathrm{person} /$ day for Damaturu, Gombe, Jalingo, Maiduguri and Yola metropolis respectively (Bogoroet al., 2014; Babalola et al., 2010; Sulaimanet al., 2016; Tsunatuet al., 2015; Dauda et al., 2003; Liman et al., 2015).

\section{Solid waste characterization for the study areas}

The results for the MSW characterization of North-Eastern capital cities is given in Table 3. The value given is for Bauchi metropolis chosen to represent waste composition for Northeastern Nigeria. 
Table 3. MSW Characterization for Northeastern Nigeria

$\mathrm{S} / \mathrm{N}$ Components $\quad$ Compositions (\%)

\begin{tabular}{lll}
\hline 1 & Organic Waste & 35
\end{tabular}

2 Paper 18

3 Wood 2

$4 \quad$ Leaves, hay and straw 20

5 Other waste 25

$\begin{array}{ll}\text { Total } & 100\end{array}$

In Table 3, it can be seen that almost all the components are decomposable with the exception of "other wastes". The organic component makes the highest percentage followed by leaves, hay and straw wastes, then by paper, wood and other wastes. This result is in line with the findings of Liman et al., 2015 and Bogorroet al., 2014.

\section{Methane emitted and Electricity generation}

In the study area, all the $\mathrm{CH}_{4}$ generated from the MSW disposed is emitted because none is captured or utilized. Table 4 shows this amount of $\mathrm{CH}_{4}$ and its potential in terms of electricity if the biogas were to be utilized for power generation.

Table 4: Methane emitted and its Electricity Generation Potential in 2017

\begin{tabular}{llll}
\hline $\mathbf{S} / \mathbf{N}$ & Cities & Methane emitted $(\mathbf{K g})$ & Electricity generated $(\mathbf{M W h})$ \\
\hline $\mathbf{1}$ & Bauchi & $14,352,82$ & 9,299 \\
$\mathbf{2}$ & Damaturu & 101,042 & 654 \\
$\mathbf{3}$ & Gombe & 378,330 & 2,451 \\
$\mathbf{4}$ & Jalingo & 173,021 & 1,121 \\
$\mathbf{5}$ & Maiduguri & 513,501 & 3,327 \\
$\mathbf{6}$ & Yola & 426,869 & 2,766 \\
\hline
\end{tabular}

As indicated in the table, Bauchi metropolis has the highest amount of methane emitted and hence quantity of electricity to be generated. These values where less than that of Ahmed et $a l ., 2016$, in which the $\mathrm{CH}_{4}$ emission was higher due to the estimation methodology which was a bit exaggerative.

The table also shows that Bauchi was followed by Maiduguri, Gombe, Yola, Jalingo and Damaturu metropolises with the electricity generation values amounting to 9,299 $\mathrm{MWh}$ (1.0615 MW), $654 \mathrm{MWh}$ (0.0747 MW), 2,415 MWh (0.2798 MW), 1,121 MWh (0.128 MW), 3,398 MWh (0.3798 MW) and 2,766 MWh (0.3157 MW) respectively. This simply 
shows that the quantity of electricity to be generated depend on the amount of methane emitted.

\section{CONCLUSION AND RECOMMENDATION}

This research assesses the amount of methane emitted and its energy potential in terms of electricity from MSW landfills in North-eastern capital cities of Nigeria. The municipal solid waste and its methane emissions were estimated for the year 2017 using IPCC methodology. It was found that the total MSW generated in Bauchi, Damaturu, Gombe, Jalingo, Maiduguri and Yola in that year are 196,643,750; 14,114,185; 52,615,845; 23,956,410; 71,625,775 and $59,111,750 \mathrm{~kg} /$ year respectively. Municipal solid waste generation was found to be largely proportional to population size. With growing population in the study region, the amount of waste generated must be well managed to guide against its negative impacts on both human health and the environment.

Further to this, the total amount of methane emitted was determined using IPCC (FOD) method. From the results obtained 1,435,282 kg was estimated for Bauchi metropolis which is the highest in the region with $101,042 \mathrm{~kg}$ for Damaturu as the least; potential electricity generation was obtained to be 9,299 MWh (1.0615 MW) and 654 MWh (0.0747MW) for Bauchi and Damaturu respectively in the year 2017. Comparing with the 13.2 MW power supplied to Bauchi metropolis from the national grid in 2017, additional production of 1.062 MW from the emitted methane gas would have increased power supply by $0.08 \%$. This means more than fifty thousand additional people would have had access to electricity at the existing $21 \mathrm{~W}$ energy per capita for 2017.

This shows the benefits that will be enjoyed if a sanitary landfill can be constructed so that the methaneemanating from the MSW degradation can be harnessed prudently for renewable energy production in terms of electricity.

\section{Recommendation}

It is recommended that future improvement on this work should consider collecting actual MSW data for each of the studied capital cities directly from field work. This should also be extended to cover other parts of the states and the country at large.

\section{REFERENCE}

1. Ahmed, S.I., Johari, A., Hashim, H., Lim, J.S., Jusoh, M., Mat, R \& Alkali, H., (2015). Economic and environmental evaluation of landfill gas utilization: A multi-period optimization approach for low carbon regions, Journal of International Biodeterioration \& Biodegradation, 102, 191-201.

2. Ahmed, S. I., Misau, I. M., Ibrahim, M. D., James I. B., Haruna, S. I. (2016). Renewable Energy and Environmental Benefits through Municipal Solid Waste Landfilling in Bauchi, Nigeria. African Journal of Renewable and Alternative Energy, 1(2), 149 - 154

3. Amini, H.R., Reinhart, D.R., 2011. Regional prediction of long-term landfill gas to energy potential. Waste management, 31, $2020-2026$

4. Babalola, A., Tsenbaya, H.I., Busu, I \&Rafee, M.M., (2010). The practice and challenges of solid waste management in Damaturu, Yobe State Nigeria, Journal of Environmental protection, 3, $384-388$

5. Barros, M.R., Filho, T.G.L \& Da Silva T.R., (2014). The electric energy potential of landfill biogas in Brazil. Energy Policy. 65,150 - 164.

6. Bhattacharyya, J.K., (2014). Solid \& Hazardous Waste Management Division, 1st Ed., National Environmental Engineering Research Institute Nehru Marg, Nagpur, India, $440-449$. 
7. Boltze, U \& De-Freitas, H.M., (1997). Monitoring Gas Emissions from Landfill Sites, Waste Management and Research, 15, 463 - 476.

8. Borjesson, G., Sundh, I \&Svensson, B., (2004). Microbial oxidation of $\mathrm{CH}_{4}$ at different temperatures in landfill cover soils, Federation of European Microbiological Societies, 48, $305-312$, UK.

9. Bogoro, A.G., Bukar, A.G., Samson, M.N \& Rasheed O., (2014). Economic factors that determine the quantity and Characteristics of Solid Waste in Bauchi Metropolis, Nigeria. IOSR Journal of Environmental Science, Toxicology and Food Technology, 8 (6), $1-7$

10. Chaudhary, R \& Garg, R., (2014). Comparisons of Two Methods for Methane Emission at Proposed Landfill Site and Their Contribution to Climate Change, International Journal of Application or Innovation in Engineering \& Management, 3, 77 - 83.

11. Dauda, M. \&Osita O. O., 2003. Solid waste management and re-use in

12. Maiduguri, Nigeria. IN: Harvey, P. (ed). Towards the millennium development

13. goals - Actions for water and environmental sanitation: Proceedings of the 29th

14. WEDC International Conference, Abuja, Nigeria, $22-26$.

15. Felix, F. B., \& Yomi, G. B. (2013). Appraisal of the Economic Geology of Nigerian Coal Resources, Journal of Environment and Earth Science, 2224 - 3216.

16. Guangyu, Y., (2011). Point Sources of Pollution: Local Effects and its Control. Journal of solid waste, 1(3). 10-17.

17. Hoklis, C \& Sharp, A., (2014). Greenhouse Gas Emission from Municipal Solid Waste in Phnom Penh, Cambodia, GMSARN International Journal, 8, 73 - 78.

18. IPCC, (2007a). Summary for policymakers. In: Metz, B., Davidson, O.R., Bosch, P.R., Dave, R \& Meyer L.A. (Eds.), Climate Change 2007: Mitigation. Contribution of Working Group III to the Fourth Assessment Report of the Intergovernmental Panel on Climate Change. Cambridge University Press, Cambridge, UK and New York, USA.

19. Ishigaki, T., Chung, C.V., Sang, N.N., Ike, M., Otsuka, K., Yamada, M \& Inoue Y., (2008). Estimation and field measurement of methane emission from waste landfills in Hanoi, V Vietnam, Journal of Material Cycles and Waste Management, 10 (2008), 165172.

20. Jarusombat, S. Et al., (2002). Factors influencing treatment decisions of hazardous waste generators". A case study of factories in the Bangkok region, Waste Management and Research, 20 (6), 79 - 86.

21. Johari, A., Ahmed, S.I., Hashim, H., Alkali, H. \& Ramli, M., (2012). Economic and environmental benefits of landfill gas from municipal solid waste in Malaysia, Renewable and Sustainable Energy Reviews Journal, 16, 2907-2912.

22. Liman, A., Sahabo, I \&Ngah, I., (2015). Comparative analysis of municipal solid waste generation rates and compositions in Yola, Adamawa state of Nigeria, International Journal of innovative science \& technology, 2, $25-33$.

23. Lou, X.F. \& Nair, J., (2009). The impact of landfilling and composting on greenhouse gas

24. emissions - A review, Bioresource Technology, 100, 3792-3798.

25. Mackie, K.R. \& Cooper, C.D., (2009). "Landfill gas emission prediction using Voronoi diagrams and importance sampling", Environmental Modelling \& Software, 24, 12231232.

26. Sulaiman, M.B., Maigari, A.U \&Sa'idu, D., (2016). Impact of municipal solid waste dumps on surrounding soil and groundwater in Gombe, Nigeria. International Journal of Science, Environment and Technology, 5(5), 3059 - 3068. 